\title{
REMEMBERING KATHLEEN GOUGH ... HER STUDY AND SUPPORT OF SOCIALISM
}

\author{
Eleanor Smollett \\ University of Regina
}

My relationship with Kathleen was a friendship of many years' duration, founded and maintained by our shared intellectual and political concern that socialist development should be studied, described and supported. Kathleen was committed to socialism. She considered it the road most likely to lead towards a more just and humane way of life. Consequently, she followed all socialist-oriented peoples' struggles with keen anxiety and hope.

In her writings on south India she faithfully reported the contributions of the communist movement to struggles for justice among the rural poor; she always named the political parties involved explicitly, regardless of how North American academia might be reacting at the moment to the word "communist."

After her first visit to Vietnam in 1976, she wrote the first of her two books on Vietnam (Ten Times More Beautiful: The Rebuilding of Vietnam, 1978), her loving portrait of the Vietnamese people's struggle to rebuild their devastated land and of their efforts, in the face of overwhelming obstacles, to maintain socialist principles as they did so. Kathleen was a realist. Her writings on Vietnam paint no utopia. Like all her work, they are full of the concrete details of people's everyday problems and circumstances and provide the full complexity of the context in which people chose how they would act. The errors, the contradictions, the carry-over of thinking from the past, the material limitations are all there. But her overall conclusion is clear. She observed. She listened to what people told her about their lives. And it was evident to her that the people were benefiting immeasurably through socialist development.

She was able to see this because of the nature of the questions she asked the people and herself. She did not arrive in Vietnam with a checklist of what a society must accomplish to be "really socialist," as so many Marxists in academia were wont to do. She looked at the direction of movement, at the 
concrete gains from where the Vietnamese had begun. And she compared what had been achieved in Vietnam with the situation she knew so thoroughly in India - the increases she saw in Vietnam in health care, education, pensions, in the diversity and availability of employment; improvements in agriculture that directly benefited poor rural people; improvement in conditions for women to develop their talents; advances in popular participation in solving problems; a sense of hope-she compared all these results of socialist development in Vietnam with India, and the picture was clear. Observing socialist development from the point of view of the Vietnamese themselves, rather than as judged against a hypothetical ideal system, she found the people's stated enthusiasm credible.

Kathleen's modesty and gentleness of character was combined with an absolute toughness in face of intellectual or political intimidation. She was scrupulously honest in what she said and wrote. When she was uncertain, she said so. When her thinking changed, she said so. If there were consequences, she bore them. Confronted with China's attacks on Vietnam, she found herself reexamining her views of Chinese foreign policy. This led to re-examination of Soviet foreign policy as well and to a comparison of what each had contributed to Vietnam. From there, she began also to re-evaluate some of her longheld negative assumptions about life within the Soviet Union. When this strained some of her long-term friendships, she bore it. Suddenly, she experienced difficulty in publishing some of what she had learned in a 1982 visit to Cambodia; the material remained unpublished for some time until we contacted New World Review, who gladly printed what they could of it.

Kathleen was one of my several mentors when I did a year of field work in India in 1964, and our friendship dated from that time. Since 1971, my own field work has been in Bulgaria. I did not return to work in India again, but comparison with what I had experienced there always affected my observations of socialist development in Bulgaria. So Kathleen and I had that common perspective to share.

Just as Kathleen expressed her own best understanding of social realities at any given time, regardless of the political winds of the moment, she also supported the work of other scholars whom she trusted, whether or not their views were popular with established experts. I experienced this personally in her consistent support through the years of my own research and writing about socialist development in Bulgaria. When I gave her articles, she read them at once, provided comparisons, criticisms and encouragement. When I wrote what I observed and what Bulgarian village people told me-of their devotion to socialist co-operative farming and the enormous improvement in standard of living and fulfilment at work that it brought them-I met the scepticism of the expert referees at journals and granting agencies, who rejected the work as naïve. Kathleen helped to get at least some of it into print. 
I remember one moment in particular in the 1970 s early in my work in Bulgaria. I had written about the early days of co-operative farming in the village of Kirilovo and had quoted directly from a tape-recorded life history account by Todora Eneva Mineva. Todora had detailed her former extreme poverty, the step-by-step building up of the co-operative, the easing of the farmers' labour as they mechanized, the new houses they were able to build for themselves. She described the pleasures of working in a team, that they could sing and act parts as they worked-one could be the bridegroom, another the mother-in-law-and she said that women go to work now with flowers in their hair. Beside the phrase "flowers in their hair," the rejecting referee wrote "heavy ... !" It was only with the comfort and support of Kathleen that it was possible to continue working after moments like that. I stand personally bereaved at the loss of that support.

Kathleen herself knew about scepticism. In her 1977 article, "The Green Revolution in South India and Vietnam,"' in speaking about Vu Thang cooperative in Vietnam, she wrote:

The result is a community which is still sparsely supplied by western standards, but is immeasurably more prosperous, comfortable, egalitarian, cheerful and optimistic than the villages of Thanjavur. I find it hard to describe the joy and pride, even the elation, that I found there, for fear I am not believed, so I will stick to material matters.

Kathleen's concern with life in socialist countries continued to the end of her life. Her last book was Political Economy in Vietnam (1990), her second book about Vietnam. I wonder how she felt about the headlong rush straight into the arms of the World Bank and the IMF, which had already begun before she died - as the socialist bloc began to come apart, and a generation of people began their slide into the Third World, confident that "the market equals democracy." I do not know what her thoughts were about this. I hope that her political work will bear fruit at a future time and that the present period of reaction will be followed by renewed endeavours to build socialism and new advances in its accomplishment.

\section{References Cited}

Gough, Kathleen

1977 The "Green Revolution" in South India and North Vietnam. Social Scientist 61(August):48-64. Also in Bulletin of Concerned Asian Scholars 10(1, January-March 1978) and in Monthly Review 29(8, 1978).

1978 Ten Times More Beautiful: The Rebuilding of Vietnam. Vancouver: New Star Books; New York: Monthly Review Press.

1990 Political Economy in Vietnam. Berkeley, CA: Folklore Institute. 